\title{
Majority of Parents Involve in Girls Higher Secondary Schools in Jammu and Kashmir: A Case Study of Anantnag \& Kulgam Districts of Kashmir Province.
}

\author{
Mohd Shamim ${ }^{1}$, Tabasum Rashid ${ }^{2}$ and Ruhee Rashid ${ }^{3}$ \\ ${ }^{1}$ Department of Education Lovely Professional University Jalandhar (Punjab) , ${ }^{2}$ Higher Secondary School \\ Yaripora Kulgam Kashmir $\left(J \&\right.$ \&), $J$ \& K Department of Education, ${ }^{3}$ Department of Education Kashmir \\ University, Srinagar $(J \& K)$.
}

\begin{abstract}
As majority of people give top priority to their boys as compared to girls and girls are consciously ignored and parents give less importance to girls education. Therefore, there is possibility for girls to become victim of various types of psychological problems. The study aimed to explored parents' majority of parents involve in girls higher secondary schools in Jammu and Kashmir with reference to girl student's problems in Anantnag \& Kulgam Districts of Kashmir Province( $J \& K)$. Understanding of students' problems relating to their education like not doing home assignments, absenteeism from school, lack of interest in learning, health related problems like any typical disease (s), psychological problems like students' inferiority complexes, telling lies, remaining disturbed, being isolated and introvert in school, interpersonal relations and maladjustment problems, personal family related problems like separation between parents, financial problems. Such problems affect on students' behavior at school and causes lack of interest in learning. Information from parents about the nature of students' problems can help teachers in understanding problems. At the same time parents involvement in schools can raise some problems for teachers however, such problems may be controlled through proper leadership and administration.
\end{abstract}

Keywords: Girls higher secondary schools,Anantnag \& Kulgam districts, involvement of parents , psychological problems, families, teachers and financial problems.

\section{Introduction:}

An education of male child is only to educate a single person but an education of female child is the education of family. The system of school education is introduced for the purpose of educating and training the generations of the country according to the aspirations of the nation. administrators, curriculum, teachers' training institutions, teachers, students and parents equally play their particular roles in the development of the school education system, in the training and education of students, and in the achievement of the objectives of school education system. To run an education system, a specific curriculum is developed and implemented and trained teachers for certain specific school level are appointed at certain level for the purpose of educating the generations of the nation. In order to make the education system a success and to it smoothly, it is essential that all segments involved contribute sufficiently and play their required, expected and active role for the achievement of the objectives of education system as a whole.

For better and fruitful learning of students it is essential that students should be free from all kinds of problems and tensions within school environment and even at home they should provide a relaxed environment. For this purpose parents involvement is essential. Parents involvement means helping children in their reading, in doing their homework, in comprehension of text material, keeping time check on children while watching television, visiting children's schools, meeting teachers and getting information about children's progress in studies.

The learning of students and their behavior can be made better and fruitful only by getting their parents involved in their schools. Parents are copartners in the learning process of their children; as there are various problems which teachers and school alone are unable to solve. For instance there are many such learning and behavior problems that for solution of these problems parents/home / family information and cooperation is required. These problems may be of diverse kind; psychology problems, emotional problems, educational problems, health problems, economic problems, absenteeism problems, etc.

William Jeynes (2004) indicates in Meta analysis study that parental involvement is associated with higher student achievement outcomes. Nowadays parents' involvement with reference to their children's education requires more than mere at home assistance. The Centre on Families, communities, schools and children's learning (1994) indicates that parents who receive frequent and positive messages from teachers tend to become more involved in their children's education than do other parents. 
Educators have also assumed that parents' are not as involved or as interested in the progress of their adolescent children as is required. However Shaver and walls (1998) have found that parents do have a desire to be involved in the lives of their adolescent children regardless of their economic status or ethnicity Parents just are not always successful in their efforts so they tend to be more cautious in their actions. The role of family school involvement at the middle, high and higher secondary school level is determining the kinds of adult interactions that not only allow teenagers to have autonomy and respect but also meet the needs of families and schools.

Researchers report that though parents' involvement in schools facilitates students' learning at schools but there are some parents who are unable to play their active role in schools either due to their different responsibilities and time constraints or due to communication problems resulting from some sort of psychological barriers or illiteracy which prevent them from conveying their and their child's' problems to the teachers. In such circumstances it is essential for schools to facilitate parents by accommodating them through a relaxed and flexible time schedule and by arranging different meetings or conferences for them. It is also fact that some parents feel reluctance in attending schools and meets the teachers and gets information about their children's progress.

To affect change, parents must find time to participate in their children's education while schools must provide the supports necessary for them to be involved. The resulting partnerships between parents and teachers will increase students' achievement and promote better cooperation between home and school. A growing number of parents do not speak or read English well enough to communicate with teachers and administrators. Because of cultural differences, many parents' are not familiar with the expectations of their children's' schools and do not understand how to go about getting involved, even if they want to. Some parent's lack the educational background or skills they feel they need to interact with teachers and staff. For others, their own negative experiences as students make them uncomfortable going to the school.

"Teachers who feel overburdened with their teaching load may not have the time to reach out to parents. They need to be given the necessary time to contact and meet with parents. To coordinate parentteacher meetings and develop parent-involvement programs, the school may designate a parent liaison or home school coordinator" (Ballen \& Moles, 1994). Online reference retrieved on October 10, 2008.

Parents should also be active in collaborating on school curriculum to ensure that their children will have appropriate option available to them when they leave school. As O'Neill et al. (1990) present some recommendations in this regard:

1. Parents should share information with school personnel about student and family needs activities and goals

2. Parents should participate in selecting goals, the kind of learning experiences their children will have, and the kind of skills they will be taught.

3. Parents should participate with school personnel in exploring post-school options.

4. Parents may need to work with professionals and/or other parents to develop more appropriate options when service gaps exist.

Higher secondary school level is the most crucial level of schooling for students, especially for girl students. At this stage different mode of physical developmental changes occur. Parallel to this various psychological, emotional, and social. etc and changes also take place at this crucial age level. In respect to female students, it is rather essential to be more conscious about female students' problems of specific nature as compared to male students. So, it becomes mandatory that parents should be involved in schools in order to understand the nature of these problems and to extend cooperation for a quick and workable solution to these problems.

It is generally observed in Anantnag \& Kulgam districts of Kashmir Province, where female are given lower social status than male, female students at girls higher secondary schools suffer many problems and due to presence of these problems, their studies are also affected. Mostly, these problems have their roots in educational social, psychological, health, absenteeism from schools or economic problems.

As researches suggest that involvement of parents in schools have positive effect on students' achievement as well as in solving their problems of different nature, so that researcher, keeping in view the situation in Anantnag \& Kulgam districts girls higher secondary schools ,decided to conduct a research study to find out the role of parents involvement in girls higher secondary schools and its impact on solving students problem of different nature like educational problems, psychological problems, health problems and social problems etc.

\section{Statement of the Problem:}

Generally, girl students of higher secondary school level (class XI-XII) Kashmir Province face typical problems of various natures at school and due to such problems they create difficulties forteachers and studies are also affected. The present study was conducted to appraise parents involvement in girls higher secondary 
schools with reference to students problems. The study aimed at exploring effectiveness of parents in girls higher secondary schools in Anantnag \& Kulgam districts and its impact on solving girl students problems.

\section{Objectives of the Study:}

The study was designed to achieve the following objectives:

1. To find out nature of problems that girl students' generally face at higher secondary school level.

2. To measure effectiveness of parents in girls higher secondary schools to Understanding problems of girl students.

3. To explore problems relating to parents involvement girls higher secondary schools

\section{Research Questions}

1. Do girls students face typical problems at higher secondary school level?

2. Is parents' involvement in girls higher secondary schools effective in understanding problems of girl students

3. Can parents' involvement in girls higher secondary schools bring addition in the problems of teachers?

\section{Delimitation of the Study}

As the researcher had limited time and financial resources so the study was delimited to the

following factors:

1. Randomly selected 20 Girls Higher Secondary Schools of public sector located in Anantnag and Kulgam districts;

2. On the basis of the researchers' experience in the field of secondary education and with consultation with secondary school teachers, the following major areas of problems of girls students were in investigated in the study:
a) Educational Problems
b) Health related problems
c) Family problems

Population and sample:

All teachers teaching in girls higher secondary schools of Anantnag and Kulgam Districts of Jammu and Kashmir were the population of the study. 20 girls higher secondary schools of Government And public sector were selected randomly and then 20 teachers from each school were selected randomly for collection of data. So the total sample was 200 girls higher secondary school teachers.

\section{Demographic Data}

\section{Research Methodology:}

- Detailed information about teachers' educational and professional qualification, age, and their teaching experience in girls higher secondary school classes is mentioned below in the table No.1

Table: 1 .

\begin{tabular}{|l|l|}
\hline \multicolumn{1}{|c|}{ Sample } & Quantity \\
\hline Teachers having M.A, B.Ed, Ph.D degrees & 20 \\
\hline Teachers having M.A,B.Ed, NET(national eligibility test) & 30 \\
\hline Teachers having M.A,B.Ed. SET(state eligibility test) & 40 \\
\hline Teachers having M.A, B.Ed, M.Phil degrees & 50 \\
\hline Teachers having M.A, B.Ed degrees & 60 \\
\hline
\end{tabular}

\section{Analysis of Teachers' Responses on Questionnaire}

The above table describes that teachers are of the view that girl students certainly face problems of typical nature at school. These problems may be due to crucial stage of girls' adolescent.

Table- 2. Girl students face problems of typical nature:

\begin{tabular}{|l|l|l|}
\hline \multicolumn{1}{|c|}{ Statement } & $\begin{array}{l}\text { No. of } \\
\text { responses }\end{array}$ & Percentage \\
\hline $\begin{array}{l}\text { Girls students at higher secondary level face a lot of } \\
\text { problems of typical nature. }\end{array}$ & 170 & $85 \%$ \\
\hline
\end{tabular}

Table:3. Educational problems like absenteeism, not doing home assignment of students from school 


\begin{tabular}{|c|l|l|}
\hline Statement & $\begin{array}{l}\text { No. of } \\
\text { responses }\end{array}$ & Percentage \\
\hline $\begin{array}{l}\text { Students learning suffers a lot due to } \\
\text { absenteeism of students }\end{array}$ & 150 & $75 \%$ \\
\hline
\end{tabular}

Table: 4. Students have physical health related problems.

\begin{tabular}{|c|l|l|}
\hline \multicolumn{1}{|c|}{ Statement } & $\begin{array}{l}\text { No. of } \\
\text { responses }\end{array}$ & Percentage \\
\hline Sometimes students have some typical diseases & 130 & $65 \%$ \\
\hline
\end{tabular}

Table: No. 5. psychological problems of female students.

\begin{tabular}{|l|c|c|}
\hline \multicolumn{1}{|c|}{ Statement } & $\begin{array}{c}\text { No. of } \\
\text { responses }\end{array}$ & Percentage \\
\hline $\begin{array}{l}\text { Girls Students have often various psychological } \\
\text { problems like inferiority complex, Interpersonal } \\
\text { relations, Telling lies, Remaining disturbed, } \\
\text { reversed, Isolated, introvert. etc. }\end{array}$ & 180 & $90 \%$ \\
\hline
\end{tabular}

Table No. 6. Personal/Family problems:

\begin{tabular}{|l|l|l|}
\hline \multicolumn{1}{|c|}{ Statement } & $\begin{array}{l}\text { No. of } \\
\text { responses }\end{array}$ & Percentage \\
\hline $\begin{array}{l}\text { Students' personal or family problems like, } \\
\text { violence, separation among parents, social, and } \\
\text { financial problems disturb them. }\end{array}$ & & $83.5 \%$ \\
\hline
\end{tabular}

Table No.7. Problems associated with parents' involving in girls higher secondary schools.

\begin{tabular}{|l|l|l|}
\hline \multicolumn{1}{|c|}{ Statement } & $\begin{array}{l}\text { No. of } \\
\text { responses }\end{array}$ & Percentage \\
\hline $\begin{array}{l}\text { Parents do not come to school on time when called and } \\
\text { teachers' time is wasted due to this reason. }\end{array}$ & 125 & $65.20 \%$ \\
\hline
\end{tabular}

Table-8. Illiteracy of Parents:

\begin{tabular}{|l|l|l|}
\hline \multicolumn{1}{|c|}{ Statement } & $\begin{array}{l}\text { No. of } \\
\text { responses }\end{array}$ & Percentage \\
\hline $\begin{array}{l}\text { Most of parents are illiterate and they do not } \\
\text { understand the importance of students' problems. }\end{array}$ & 162 & $81 \%$ \\
\hline
\end{tabular}

Table-9. Parents Criticize Teachers Unjustly:

\begin{tabular}{|c|l|c|}
\hline \multicolumn{1}{|c|}{ Statement } & $\begin{array}{l}\text { No. of } \\
\text { responses }\end{array}$ & Percentage \\
\hline Most of parents criticize teachers unjustly. & 120 & 60 \\
\hline
\end{tabular}

\section{Conclusions and Recommendations:}

1. Teachers may be provided special training regarding dealing with parents of various categories. So that they may be able to explain parents about the various problems of their daughters.

2. It is suggested that in educational calendar of secondary schools there.

3. For teachers it is difficult for to manage time for parents' casual meetings. In meetings parents often blame teachers unjustly and do not try to understand the nature of their daughters' problems.

4. Understanding the nature of girl students' problems can provide teachers the data to find the solution to these problems and manage students' learning in better way.

5. Understanding nature of girl students' personal and family related problems like violence within the home separation among parents' social back ground or financial problems. Parents involvement in schools can be beneficial to understand the nature and sort of students' personal and family problems. 
6. Understanding female students' educational problems like not doing home assignments, absenteeism from school, and lack of interest in learning.

7. Understanding the nature of female students' health related problems like any typical disease (s).

8. Parents may be informed from time to time about not only educational progress but also about the behavior and the conduct of their daughters within the school.

\section{Acknowledgement:}

I am thankful to lectures of Govt. as well as private girls Higher Secondary Schools of Anantnag and Kulgam districts of Kashmir province( J \& K).

\section{References}

[1] Garner, J. (1973). "The nature of teaching and effectiveness of teachers". In : Lomax DE (ed.) 1973, The Education of Teachers in Britain, Wiley, London, pp.425-36.

[2] Hough and Duncan (1970), "The Study of Teaching", New York; Holt, Rinehart and Winston, New York. Kumar (2005). "Teacher Effectiveness and job satisfaction of Women teachers". Edutracks, Vol.4, No.7, March 2005, pp.29-30.

[3] Kagathala, A.B. (2001). "A study of the effectiveness of teachers of secondary schools in Gujarat". Journal of Education and Psychology, Vol.LIX, No.4, (July - Dec.2001), pp.26-33.2, (October 2003), pp.17-27.

[4] Ryans, D.G., (1960). "Characteristics of teachers, their description, Comparison and appraisal". Washington, D.C. American Council of Education, p.1.

[5] Amsarani, S.R. (2002). "Teacher Effectiveness of Second Language teachers in higher secondary schools". Journal of Research in Education, 2002-2003, Vol.I, No.2, (Oct. 2002), p.21.

[6] Arora, K., (1978). "Differences between effective and ineffective teachers". New Delhi; S.Chand and Company, pp.31-38.

[7] Borich (1992). "Teacher effectiveness and concluded that key behaviours characterizing effective teachers". Indian Educational Review, Vol.XXIII, No.3, (April 1992), pp.103-114.

[8] Johnson, J.R, and Rusch, F.R. "Secondary Special Education and Transition Services". Carrier Development for Exceptional Individuals, 16, no. 1 (Spring 1993).

[9] LaBahn, J. (1995). Education and parental involvement in secondary schools problems, solutions, and effects. Educational Psychology interactive. Valdosta, GA: Valdosta State University. Available online: [http://chiron.valdosta .edu/whuitt/files/parinvol.html]

[10] O’Neill, J.; Gothelef, C.; Choen, S.; Lehman, L.; and Woolf, S.A. Curriculum Approach to support the Transition to Adulthood of Adolescents with visual or dual sensory impairments and Cognitive Disabilities. New York: Hunter College of the City University of New York, (1990).

[11] Shaver, A.V., \& Walls, R.T. (1998). Effect of title I Parent involvement on student reading and mathematics achievement. Journal of research and Development in Education, 31(2), 90-97. EJ561992.

[12] William jeynes (2004) parental involvement and secondary school student Educational Outcomes: A Meta-Analysis. Harvard family research project. Harvard school of Education. Volume X, Number 4, winter 2004/2005 issue Topic: Evaluating family Involvement programs promising practices. 